\title{
国 A Case of Pulmonary Tuberculosis Accompanied by Tuberculosis Pleurisy and Tuberculosis of the Tongue
}

\section{Akciğer Tüberkülozuna Eşlik Eden Tüberküloz Plörezi ve Dil Tüberkülozu Olgusu}

Hatice Türker, Bahadır Üskül, Özge Ünal Bayraktar, Sibel Boğa, Aydın Kant, Fatma Emre Taşolar, Özkan Devran, Özlem Saniye İçmeli, Merve Çiffçi

\section{Abstract}

The incidence of extrapulmonary tuberculosis is 10 $15 \%$ of all tuberculosis cases. In the group of extrapulmonary tuberculosis cases, tuberculosis of the tongue (0.14-0.2\% of all tuberculosis cases) is the most frequent tuberculosis form of the oral cavity. It can be seen as a primary infection, which is very rare and mostly seen in young tuberculosis cases or secondarily, which is seen in the elderly and generally accompanied by active pulmonary tuberculosis. In our case, we encountered a positive sputum smear for acid-fast bacilli, high ADA level in pleural effusion, and granulomatous infection with caseification in the tongue biopsy and started to administer antituberculosis treatment. As three forms of tuberculosis could be seen together in our case, we attempted to highlight that tuberculosis of the tongue should be considered in oral cavity lesions.

\section{Özet}

Akciğer dışı tüberküloz, tüm olguların yaklaşık \%10$15^{\prime}$ ini oluşturur. Akciğer dışı tüberkülozlar içinde dil tüberkülozu, oral kavite tüberkülozlarının en sık görülenidir. Tüm tüberküloz olgularının \%0,14-0,2'sini oluşturur. Primer ve sekonder formu olabilir. Primer formu, seyrek olup sıklıkla gençlerde, sekonder formu ise ileri yaşlarda görülür ve aktif akciğer tüberkülozuna eşlik edebilir. Olgumuzda yapılan dil biyopsisinde kazeifiye granülomatöz inflamasyon, balgamda $A R B$ pozitif, plevra sıvısında ADA düzeyi yüksek saptanarak antitüberküloz tedavisi başlandı. Üç ayrı tüberküloz formunun bir arada görülmesi nedeniyle olguyu literatürün ışığı altında tartışarak, ağız içi lezyonlarında dil tüberkülozunun akılda tutulması vurgulandı.

Anahtar Sözcükler: Akciğer, dil, tüberküloz, plevral efüzyon.

Key words: Pulmonary, tongue, tuberculosis, pleural effusion.

Süreyyapaşa Training and Research Hospital for Chest

Diseases and Thoracic Surgery, İstanbul, Turkey
Süreyyapaşa Göğüs Hastalıkları ve Göğüs Cerrahisi Eğitim ve Araştırma Hastanesi, İstanbul

Submitted (Başvuru tarihi): 24.09.2012 Accepted (Kabul tarihi): 21.11 .2012

Correspondence (Iletişim): Hatice Türker, Süreyyapaşa Training and Research Hospital for Chest Diseases and Thoracic Surgery,

ìstanbul, Turkey

e-mail:drhturker@yahoo.com 
Tuberculosis is caused by Mycobacterium tuberculosis and still poses a serious public health problem in the developing world. Of all tuberculosis cases, 10 to $15 \%$ have an extrapulmonary localization (1). Extrapulmonary tuberculosis can also occur in the oral cavity, and the most frequent presentation in the oral cavity is the tuberculosis of the tongue, comprising 0.14 to $0.2 \%$ of all cases of tuberculosis $(2,3)$. Tongue tuberculosis can be primary or secondary. The primary form is rare and more common in the younger population; while the secondary form is common in the elderly and may be associated with active pulmonary tuberculosis $(4,5)$. The clearing effect of saliva, the presence of saprophytic organisms, and the protective epithelial lining normally provide resistance to infections in the oral mucosa. However, factors such as trauma, inadequate hygiene, dental extraction, smoking, irritation, pyogenic foci, and leukoplakia may favor the growth of tuberculous bacilli in this location (5).

\section{CASE}

A 52-year-old male patient presented with a three month history of difficulty in swallowing and speaking, pain in the tongue, loss of weight, cough, and night sweats. His medical history and family history were un remarkable. He had a smoking history of 35 pack-years. The physical examination revealed cachexia, inadequate oral hygiene, and a $4 \times 2 \mathrm{~cm}$ white ulcerated lesion on the right dorsolateral side of the tongue (Figure 1). He had decreased pulmonary sounds in the left basal lung area, and percussion revealed dullness in the same region. A chest $X$ ray showed bilateral non-homogeneous areas of increased density in the upper parts, micronodular infiltrations more prominent on the left, homogeneous areas of increased density in the left para-aortic region, and pleural effusion on the left (Figure 2). The pulmonary CT showed the following: a $3 \times 3.5 \mathrm{~cm}$ lesion in the apicoposterior segment with calcifications in the upper lobe of the left lung; a $3 \times 4 \mathrm{~cm}$ cavitary lesion with irregular borders in the posterior segment of the upper lobe of the right lung; multiple bilateral nodular lesions (more prominent on the left), the largest being $1.5 \mathrm{~cm}$ in diameter and lying on the pleura in the anterior segment of the left upper lobe; pleural effusion in the left lung; and multiple millimetric-size lymph nodes on stations $2 R, 4 R, 4 L$, and 5 (Figure 3).

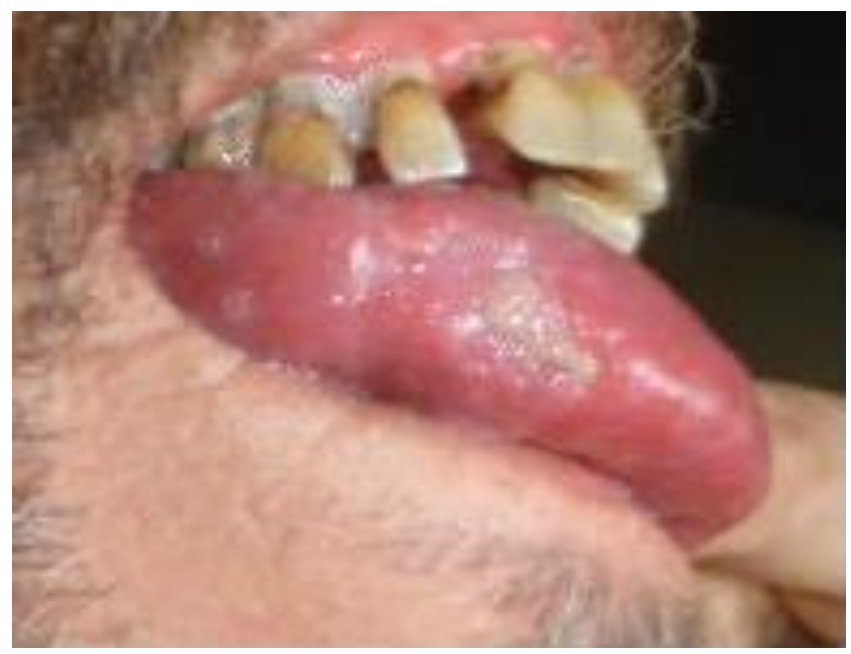

Figure 1: Ulcerous lesion on lateral side of the tongue.

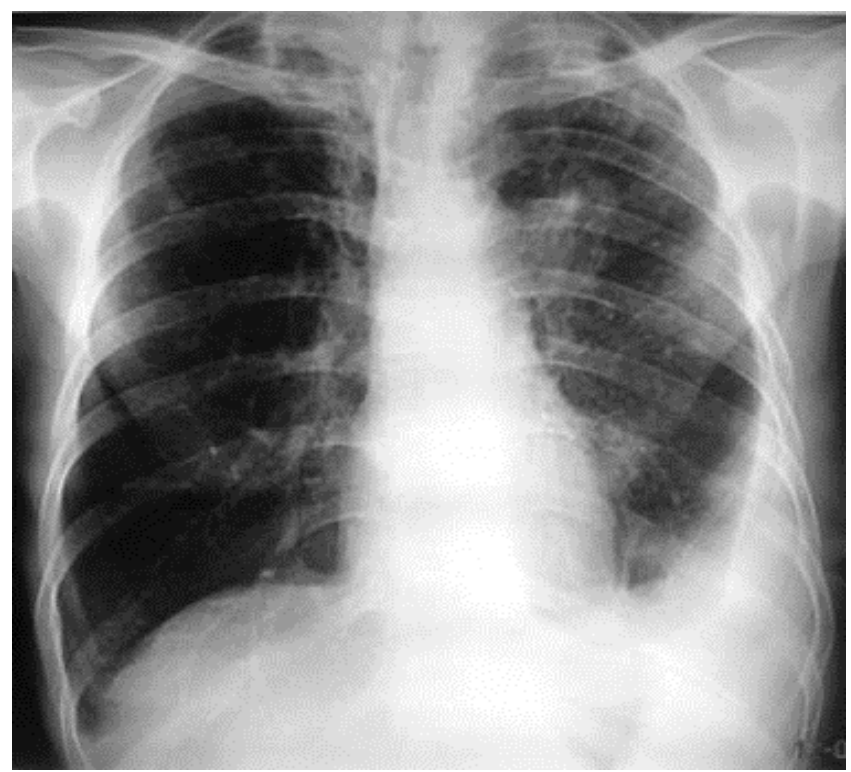

Figure 2: Chest X-ray showed bilateral non-homogeneous areas of increased density in the upper parts, micronodular infiltrations more prominent on the left, homogeneous areas of increased density in the left para-aortic region, and pleural effusion on the left.

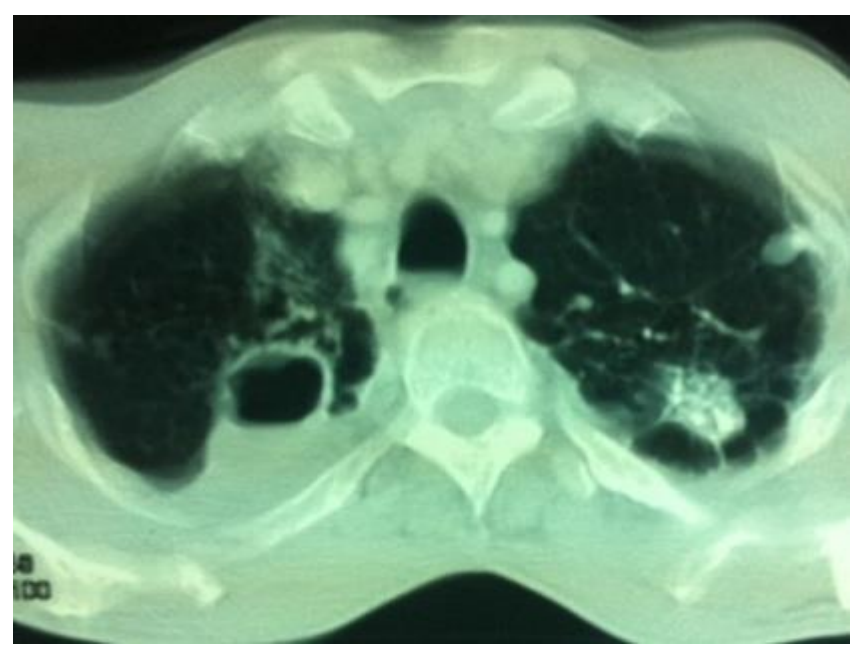

Figure 3: A cavitary lesion in the posterior segment of the upper lobe of the right lung; lesion with calcifications in the apicoposterior segment of the upper lobe of the left lung. 
Laboratory results were as follows: ESR, $90 \mathrm{~mm} / \mathrm{h}$; leukocyte count, 12400/ $\mathrm{LL} ; \mathrm{Hb}, 12.7 \mathrm{~g} / \mathrm{dL}, \mathrm{Htc}, 38.1 \%$. Biochemistry results were within the normal range. Patient was negative for HIV. Tuberculin skin test was positive (induration size of $11 \mathrm{~mm}$ ). Acid-fast bacilli (ARB) were detected in the sputum smear, and growth of mycobacteria was observed in the culture. Inflammatory granulations with caseification were seen in the tongue biopsy.

Thoracentesis on the left hemithorax revealed serofibrinous effusion. Biochemical tests confirmed the exudative character of the fluid, with chronic inflammation and lymphocyte dominance in the cytological examination. $A R B$ was negative, and ADA level was $76 \mathrm{mmol} / \mathrm{dL}$.

A six month protocol for newly diagnosed cases, which consists of isoniazid (300 mg/d), rifampicin $(600 \mathrm{mg} / \mathrm{d})$, pyrazinamide (1500 mg/d) and ethambutol (1500 mg/d), was commenced. A marked improvement of the lesion in the right lateral side of the tongue was observed on day 10 (Figure 4), and an advanced improvement was observed at the follow-up examination at one month. At the same time point, the sputum was negative for acid-fast bacilli, but with out any significant radiological improvement.

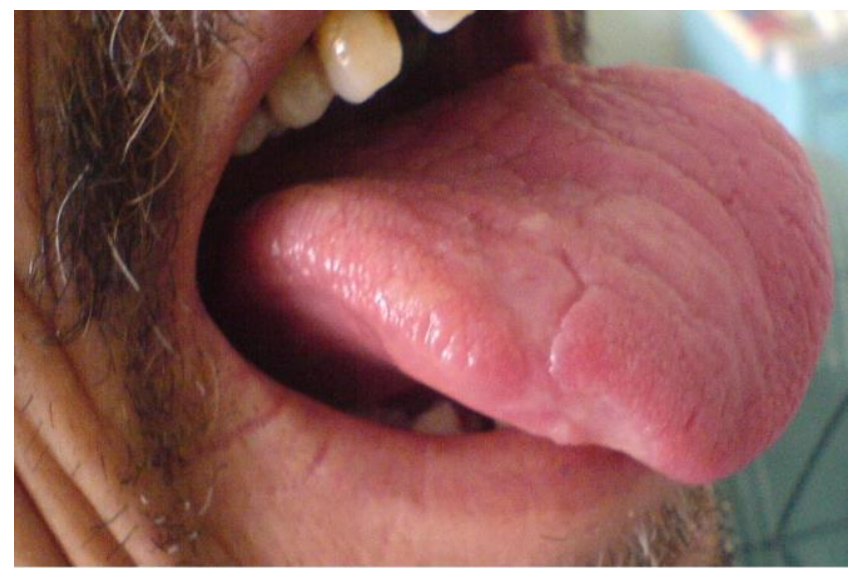

Figure 4: Disappearance of the lingual lesion at the end of one month.

The bacilli were susceptible to four major antituberculous drugs and acid-fast bacilli were negative at follow-up visits at months two and three. The chest X-ray showed improvement in the micronodular infiltrations, but pleural effusion persisted. At month six, the sputum examination was negative for acid-fast bacilli, the patient had no complaints and lingual lesions disappeared completely. Radiological signs of fibrosis and pachypleuritis were present and the treatment was discontinued (Figure 5). At present, the patient has no complaints and follow-up visits at six month intervals have been scheduled.

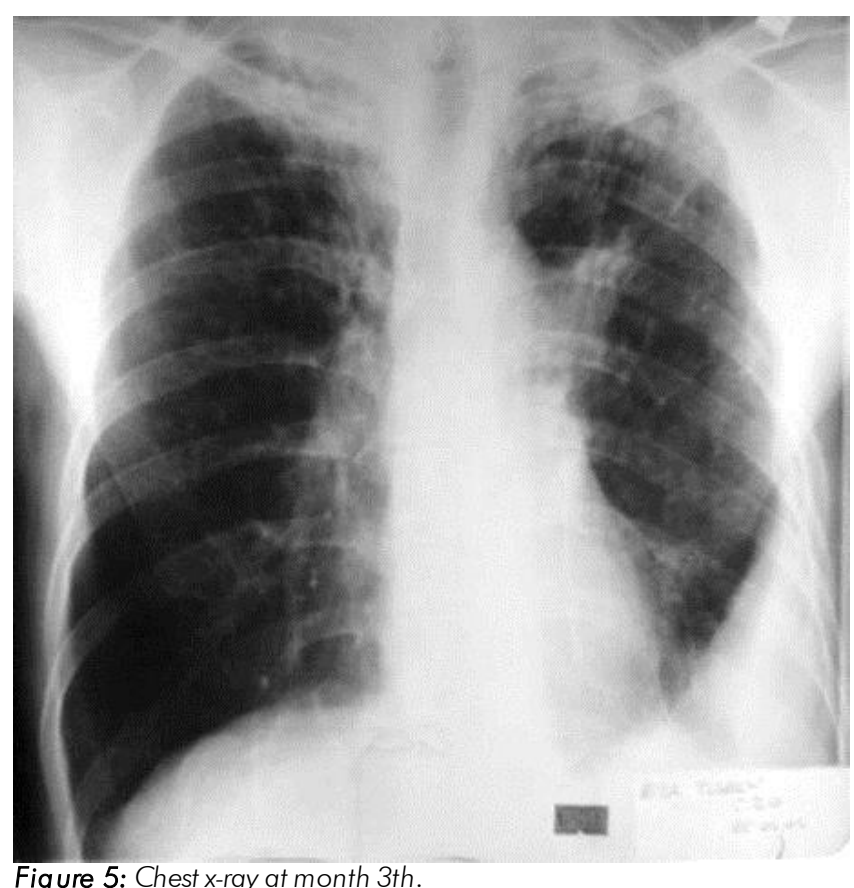

\section{DISCUSSION}

Tuberculosis in the oral cavity is rare, comprising only 0.14 to $0.2 \%$ of all cases of tuberculosis $(2,3,6)$. In the oral cavity, the most frequent form of tuberculosis is the tuberculosis of the tongue, although it can occur in other locations such as the palate, gingiva, or lips $(5,7,8)$. It may be primary or secondary. The primary form, which is more common in the young, is a rare entity frequently accompanied by cervical adenopathies. The secondary form is more common in male and elderly patients and occurs in association with active pulmonary tuberculosis (9). Likewise, tongue tuberculosis was accompanied by active pulmonary tuberculosis in our patient.

Under normal conditions, oral mucosa is resistant against the invasion of mycobacterium due to natural defense mechanisms. However, factors such as trauma, inadequate hygiene, dental extraction, smoking, irritation, pyogenic foci, and leukoplakia may favor the growth of tuberculous bacilli in the oral cavity (5). Our patient was a smoker with inadequate oral hygiene.

The tongue may be infected by direct contact with the expectorated sputum, via blood or lymphatic vessels, or spread from another infectious source in the oral cavity $(1,5)$. Lesions in the oral cavity may be ulcerous, nodular, plaque-like, or vesicular. Ulcerous lesions are more common and usually painful. Differential diagnosis should include malignancies, aphthous ulcers, syphilitic ulcers, sarcoidosis, candida infections, and foreign body granulomas (9-11). The definitive diagnosis of oral tuberculosis requires demonstration of granulomas with cas e- 
ification in the biopsy sample. In our case, tuberculosis of the tongue was confirmed by pathological examination, and concurrent pulmonary tuberculosis was confirmed by the presence of acid-fast bacilli in the sputum sample. Tuberculosis of the tongue and pulmonary tuberculosis are treated similarly. Tongue tuberculosis responds to treatment quickly due to high vascularization, leading to an improvement of symptoms within two to three months and a complete disappearance of lesions within three to five months $(8,9)$. Parallel to the literature data, in our case, an improvement in lingual lesions was observed by day 10 of the treatment.

In conclusion, tuberculosis of the tongue should be considered in the differential diagnosis of intraoral lesions in countries with a high prevalence of tuberculosis.

\section{CONFLICTS OF INTEREST}

None declared.

\section{REFERENCES}

1. lype EM, Ramdas K, Pandey M, Jayasree K, Thomas G, Sebastian $P$, et al. Primary tuberculosis of the tongue: report of three cases. Br J Oral Maxillofac Surg 2001; 39:402-3. [CrossRef]

2. Prada JL, Kindel an JM, Villanueva JL, Jurado R, SánchezGuijo P, Torre-Cisneros J. Tuberculosis of the tongue in two immunocomponent patients. Clin Infect Dis 1994; 19;200-2. [CrossRef]
3. Cakan A, Mutlu Z, Ozsöz A, Erbaycu AE, Unal T, Koyuncu $B O$. Tuberculosis of oral mucosa. Monaldi Arch Chest Dis $2001 ; 56: 315-7$.

4. Hashimoto $Y$, Tanioka H. Primary tuberculosis of the tongue: report of a case. J Oral Maxillofac Surg 1989; 47:744-6. [CrossRef]

5. Trivedi A, Patel J, Kalola J. Ulcer of the tongue as a presenting feature of pulmonary tuberculosis. Indian J Otolaryngol Head Neck Surg 2007; 59:166-7. [CrossRef]

6. Weaver RA. Tuberculosis of the tongue. JAMA 1976; 235:2418. [CrossRef]

7. Sharma AB, Laishram DK, Sarma B. Primary tuberculosis of tongue. Indian J Pathol Microbiol 2008; 51:65-6. [CrossRefl

8. Garg RK, Singhal P. Primary tuberculosis of the tongue: a case report. J Contemp Dent Pract 2007; 4:1 -4.

9. İnönü H, Sönmez SÖ, Dulkar G, Güngen AC, Türkkanı M, Demirağ F. Pulmoner tüberküloza sekonder dil tüberkülozu-Olgu sunumu. Akciğer Arşivi 2005; 6:160-2.

10. Mackowiak PA. A 40-Year-old man with tongue lesions. Clin Infect Dis $2011 ; 52: 1276-7$. [CrossRef]

11. Hussaini J, Mutusamy S, Omar R, Rajago palan R, Narayanan $P$. Base of tongue tuberculosis: a case report. Acta Med Iran 2012; 50:151-2. 